\title{
UJI AKTIVITAS ANTIBAKTERI EKSTRAK ETANOL RIMPANGLENGKUAS PUTIH (Alpinia galanga L. Willd) TERHADAPBAKTERI Klebsiella pneumoniae ISOLAT URIN PADA PENDERITA INFEKSI SALURAN KEMIH
}

\author{
Arini Shintia ${ }^{1)}$, Fatimawali ${ }^{1)}$, Jainer Pasca Siampa ${ }^{1)}$ \\ ${ }^{1)}$ Program Studi Farmasi FMIPA UNSRAT Manado, 95115
}

\begin{abstract}
White galangal rhizome is a plant that has properties such as antifungal and antibacterial. White galangal rhizome contains of active compounds, namely flavonoid, phenol and terpenoid compounds which can inhibit microbes. This study aimed to determine the antibacterial activity of ethanol extracts of white galangal rhizome against Klebsiella pneumoniae urine isolate in patients with urinary tract infections. White galangal rhizome plants were extracted using $96 \%$ ethanol solvent. Antibacterial activity test was performed using the disc and wells method. The result showed that ethanol extracts of white galangal rhizome has antibacterial activity against the bacteria Klebsiella pneumoniae. In the disc method with concentrations of $80 \%, 60 \%, 40 \%, 20 \%$ and $10 \%$ the diameter of the inhibition zone formed are 9,8 $\mathrm{mm} ; 9 \mathrm{~mm} ; 7,8 \mathrm{~mm} ; 7,9 \mathrm{~mm}$ and 7,7 mm. Inhibition of the disc method is categorized as medium because the diameter of the zone formed is only around an average of 5-10 mm. Whereas in the wells method for concentrations of $80 \%, 60 \%, 40 \%$, $20 \%$ and $10 \%$ the diameter of the inhibition zone are $11,3 \mathrm{~mm} ; 10,3 \mathrm{~mm} ; 9,3 \mathrm{~mm} ; 6,3 \mathrm{~mm}$ and 2,6 mm. The inhibitory ability at concentrations of $80 \%$ and $60 \%$ is categorized as strong because it has an average of 10-20 mm, for concentrations of $40 \%$ and $20 \%$ are categorized as medium, because it has an average inhibition zone diameter of 5-10 mm, and for concentration of $10 \%$ is categorized as weak because it has a inhibition diameter $<5$ mm.
\end{abstract}

Keywords: White Galangal Rhizome (Alpinia galanga L. Willd), Klebsiella pneumonia

\begin{abstract}
ABSTRAK
Rimpang lengkuas putih merupakan tanaman yang memiliki khasiat di antaranya sebagai antifungi dan antibakteri. Rimpang Lengkuas putih mengandung golongan senyawa aktif yaitu golongan senyawa flavonoid, fenol dan terpenoid yang dapat menghambat mikroba. Penelitian ini bertujuan untuk mengetahui aktivitas antibakteri ekstrak etanol rimpang Lengkuas putih terhadap bakteri Klebisella pneumoniae isolat urin pada penderita infeksi saluran kemih. Tanaman rimpang Lengkuas putih di ekstraksi dengan menggunakan pelarut etanol 96\%. Uji aktivitas antibakteri dengan metode cakram dan sumuran. Hasil penelitian menunjukkan bahwa ekstrak etanol rimpang Lengkuas putih memiliki aktivitas antibakteri terhadap bakteri Klebsiella pneumoniae. Pada metode cakram dengan konsentrasi 80\%, $60 \%, 40 \%, 20 \%$ dan 10\% diameter zona hambat yang terbentuk ialah 9,8 mm; $9 \mathrm{~mm} ; 7,8$ $\mathrm{mm} ;$ 7,9 $\mathrm{mm}$ dan 7,7 $\mathrm{mm}$. Penghambatan pada metode cakram dikategorikan sedang karena diameter zona yang terbentuk hanya berkisar pada rata-rata 5-10 $\mathrm{mm}$. Sedangkan pada metode sumuran untuk konsentrasi $80 \%, 60 \%, 40 \%, 20 \%$ dan $10 \%$ diameter zona hambatnya ialah $11,3 \mathrm{~mm} ; 10,3 \mathrm{~mm} ; 9,3 \mathrm{~mm} ; 6,3 \mathrm{~mm}$ dan 2,6 mm. Kemampuan penghambatan pada konsentrasi $80 \%$ dan $60 \%$ di kategorikan kuat karena memiliki diameter zona hambat rata-rata 10-20 mm, untuk konsentrasi $40 \%$ dan $20 \%$ di kategorikan sedang, karena memiliki diameter zona hambat rata-rata $5-10 \mathrm{~mm}$, dan untuk konsentrasi $10 \%$ di kategorikan lemah karena memiliki diameter zona hambat $<5 \mathrm{~mm}$.
\end{abstract}

Kata Kunci: Rimpang lengkuas putih (Alpinia galanga L. Willd), Klebsiella pneumoniae 


\section{PENDAHULUAN}

Penyakit infeksi merupakan salah satu masalah dalam dunia kesehatan (Rambiko, 2016). Penyakit infeksi pada manusia salah satunya disebabkan oleh infeksi bakteri patogen. Beberapa tahun terakhir ini, bakteri patogen yang resisten terhadap obat semakin banyak dikarenakan pemakaian obat antimikroba komersil yang tidak tepat pada pengobatan penyakit infeksi (Merchese and Shito, 2001; Karaman et al., 2003 dalam Aliero et al., 2008). Pengobatan penyakit infeksi umumnya menggunakan antibiotik. Pemakaian antibiotik secara rasional sudah menjadi keharusan. Ketidakrasionalan penggunaan dan pemakaian yang tidak tepat akan menyebabkan munculnya banyak efek samping dan resistensi bakteri (Sutrisna, 2012). Situasi tersebut ditambah dengan efek samping yang tidak diinginkan dari beberapa obat antibiotik dan kebutuhan yang mendesak untuk penyembuhan penyakit infeksi. Masalah-masalah di atas merupakan problem yang serius dalam dunia kesehatan, sehingga mendesak para ilmuwan untuk mencari obat antibakteri yang baru yang berasal dari tanaman (Merchese and Shito, 2001; Karaman et al., 2003 dalam Aliero et al., 2008).

Rimpang Lengkuas putih mengandung kurang lebih $1 \%$ minyak atsiri berwarna kuning kehijauan. Selain itu rimpang Lengkuas juga mengandung resin yang disebut galangol, kristal berwarna kuning yang disebut kaemferid, galangin, kadinen,

heksabidrokadalen hidrat, kuersetin dan amilum (sinaga, 2005). Hasil penapisan fitokimia menujukkan bahwa ekstrak etil asetat dan ekstrak etanol rimpang Lengkuas putih mengandung flavonoid, tanin, kuinon dan steroid atau terpenoid. Rimpang Lengkuas putih memiliki kandungan senyawa flavonoid yang diduga dapat menghambat pertumbuhan bakteri yang telah resisten terhadap antibiotik (Kusriani dan shofia, 2015).

Infeksi Saluran Kemih (ISK) adalah suatu keadaan yang disebabkan karena adanya invasi bakteri pada saluran kemih. Infeksi saluran kemih disebabkan oleh bakteri Escherechia coli, Klebsiella pneumoniae dan Pseudomonas aeruginosa (Tessy \& Suwanto, 2001). Antibiotik yang digunakan untuk pengobatan ISK sebagian besar yakni fluoroquinolon dan nitrofurantoin (Useng, 2014).

Salah satu keanekaragaman hayati yang mempunyai banyak manfaat yaitu Lengkuas putih (Alpinia galanga L. Willd). Lengkuas putih (Alpinia galanga $\mathrm{L}$. Willd) merupakan anggota familia Zingiberaceae. Rimpang lengkuas mudah diperoleh di Indonesia dan manjur sebagai obat gosok untuk penyakit jamur kulit (panu) sebelum obat-obatan modern berkembang seperti sekarang. Lengkuas telah dipelajari oleh ilmuwan terdahulu, ditemukan kandungan bermacam-macam khasiat lengkuas diantaranya sebagai antifungi dan antibakteri. Hal ini dibuktikan dengan penelitian Yuharmen dkk (2002) yang melihat aktivitas penghambatan oleh minyak atsiri dan fraksi methanol rimpang Lengkuas pada beberapa spesies bakteri dan fungi. 
Menurut penelitian Puput (2018) ekstrak rimpang Lengkuas putih mempunyai daya antibakteri. Berdasarkan latar belakang di atas maka peneliti merasa perlu untuk melakukan suatu penelitian yang bertujuan untuk membuktikan aktivitas antibakteri dari ekstrak etanol rimpang Lengkuas putih (Alpinia galanga L. Willd) terhadap bakteri Klebsiella pneumoniae isolat urin pada penderita infeksi saluran kemih.

\section{METODOLOGI PENELITIAN}

\section{Waktu dan Tempat Penelitian}

Penelitian ini dilakukan pada bulan Mei 2019 - Juli 2019 di laboratorium Farmasi Lanjutan Program Studi Farmasi Fakultas Matematika dan Ilmu Pengetahuan Alam Universitas Sam Ratulangi Manado.

\section{Alat dan Bahan}

Alat

\begin{tabular}{|c|}
\hline 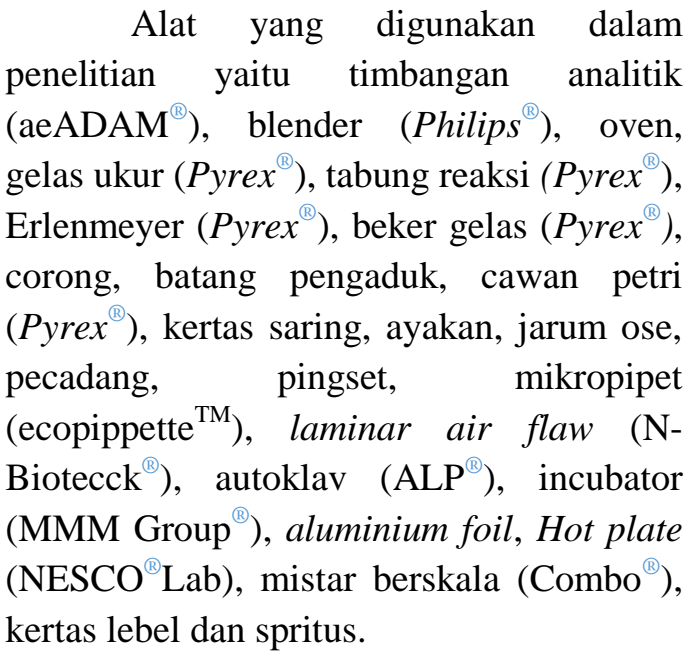 \\
\hline
\end{tabular}

\section{Bahan}

Bahan yang digunakan dalam penelitian ini yaitu bakteri Klebsiella pneumoniae, ekstrak rimpang Lengkuas putih, etanol 96\%, aquades, media nutrient agar (NA), kertas cakram, kertas cakram antibiotik, Ciprofloxacin, $\mathrm{NaCl} \quad 0,9 \%, \quad \mathrm{H}_{2} \mathrm{SO}_{4} \quad 0,36 \quad \mathrm{~N}$ dan $\mathrm{BaCl}_{2} 2 \mathrm{H}_{2} \mathrm{O} 1,175 \%$, larutan McFarland dan CMC $1 \%$.

\section{Prosedur Kerja \\ Pengambilan Sampel}

Sampel yang digunakan diambil dari Desa Kolongan Tetempangan, Kecamatan Kalawat, Kabupaten Minahasa Utara, Sulawesi Utara. Sampel yang diambil adalah bagian rimpang Lengkuas putih.

\section{Preparasi Sampel}

Pada tahap awal sampel rimpang Lengkuas putih ditimbang dengan berat $2 \mathrm{~kg}$. Selanjutnya dicuci dibawah air mengalir dengan tujuan untuk menghilangkan pengotor. Sampel kemudian dirajam sebelum dikeringkan. Pengeringan sampel dilakukan dengan cara di oven pada suhu $40^{\circ} \mathrm{C}$. Selanjutnya sampel diblender hingga menjadi serbuk dan ditimbang. Serbuk yang dihasilkan di ayak dengan ayakan, hingga diperoleh serbuk halus.

\section{Pembuatan Ekstrak}

Metode yang digunakan untuk mengekstraksi sampel rimpang Lengkuas putih (Alpinia galanga L.Willd) yaitu dengan metode maserasi. Sampel ditimbang sebanyak $150 \mathrm{~g}$, kemudian dimasukkan ke dalam wadah tertutup rapat. Sampel yang telah ditimbang di ekstraksi dengan $750 \mathrm{~mL}$ pelarut etanol 96\% pada suhu kamar selama 3 hari sambil sesekali diaduk. Setelah 3 hari sampel disaring 
menggunakan kertas saring menghasilkan filtrat satu. Sisa sampel di maserasi kembali dengan $450 \mathrm{~mL}$ pelarut etanol $96 \%$ selama 2 hari sambil sesekali diaduk kemudian disaring dengan kertas saring dan diperoleh filtrat dua. Sisanya dimaserasi kembali dengan $450 \mathrm{~mL}$ pelarut etanol $96 \%$ selama 2 hari sambil sesekali diaduk kemudian diperoleh filtrat tiga. Filtrat satu, dua dan tiga kemudian dikumpulkan dan diuapkan menggunakan inkubator, sehingga diperoleh ekstrak kental Lengkuas putih. Ekstrak kental yang diperoleh disimpan dalam wadah tertutup dan dimasukkan dalam lemari pendingin.

\section{Sterilisasi Alat}

Sebelum alat digunakan harus disterilisasi terlebih dahulu dengan cara dibungkus menggunakan aluminium foil kemudian dimasukkan ke dalam autoklaf dan disterilisasi selama 15 menit.

\section{Pembuatan Media Dasar dan Media Pembenihan}

Diambil Nutrient Agar (NA) sebanyak 5,6 g dilarutkan dalam 200 $\mathrm{mL}$ aquadest menggunakan erlenmeyer. Setelah itu, media dihomogenkan dengan stirer diatas penangas air sampai mendidih. Media yang sudah homogen ini disterilkan dalam autoklaf pada suhu $121^{\circ} \mathrm{C}$ selama 15 menit, kemudian didinginkan sampai suhu \pm $45-50^{\circ} \mathrm{C}$. Media dasar dan media pembenihan digunakan dalam pembuatan media pengujian sebagai lapisan dasar dan lapisan kedua.

\section{Regenerasi Bakteri Uji}

Bakteri Klebsiella pneumoniaee yang akan di ujikan harus terlebih dahulu diregenerasikan. Hal pertama yang dilakukan yaitu membuat media miring nutrient agar (NA). Media (NA) dituangkan kedalam tabung reaksi kemudian diletakkan pada posisi miring dan di biarkan hingga memadat. Selanjutnya bakteri uji digoreskan ke agar miring nutrient agar (NA) dan di inkubasi pada suhu $37^{\circ} \mathrm{C}$ selama 24 jam.

\section{Pembuatan Larutan Mc. Farland 0,5} (Standar Kekeruhan)

Larutan $\mathrm{H}_{2} \mathrm{SO}_{4} 1 \%$ sebanyak $9,95 \mathrm{~mL}$ dicampurkan dengan larutan $\mathrm{BaCl}_{2}$ $.2 \mathrm{H}_{2} \mathrm{O} 1,175 \%$ sebanyak $0,05 \mathrm{~mL}$ dalam erlenmeyer. Kemudian dikocok sampai terbentuk larutan yang keruh. Kekeruhan ini dipakai sebagai standar kekeruhan suspensi bakteri uji.

\section{Pembuatan Suspensi Bakteri Uji}

Bakteri uji Klebsiella
pneumoniae yang telah diregenerasi di ambil dengan jarum ose lalu dimasukkan ke dalam tabung reaksi berisi $5 \mathrm{~mL}$ larutan $\mathrm{NaCl}$ steril $0,9 \%$. Dan suspensi yang telah terbentuk disetarakan kekeruhannya dengan larutan standar McFarland 0,5.

\section{Larutan Uji}

Larutan uji dibuat dari hasil ekstraksi yang diperoleh kemudian diencerkan menggunakan aquadest sebanyak lima kali pengenceran dengan masing-masing konsentrasi $80 \%, 60 \%$, $40 \%, 20 \%$ dan $10 \%$ dengan menggunakan rumus : 


$$
\mathrm{M}_{1} \times \mathrm{V}_{1}=\mathrm{M}_{2} \times \mathrm{V}_{2}
$$

\section{Larutan Kontrol Positif}

Larutan kontrol positif dibuat dari sediaan obat tablet Ciprofloxacin 500 mg, dengan cara di ambil 1 tablet kemudian digerus dan di timbang seberat $65 \mathrm{mg}$ Selanjutnya di encerkan dalam $50 \mathrm{~mL}$ aquadest. Selanjutnya dibuat dengan cara di ambil $1 \mathrm{~mL}$ larutan dan ditambahkan aquadest hingga $10 \mathrm{~mL}$ untuk memperoleh larutan Ciprofloxacin $5 \mu \mathrm{g} / 50 \mu \mathrm{L}$.

\section{Uji Aktivitas}

\section{a. Metode Cakram}

Pada pengujian dengan metode cakram, yaitu sebanyak $15 \mathrm{~mL}$ media Nutrient Agar (NA) dituangkan ke dalam cawan petri dan dibiarkan hingga menjadi padat. Kemudian dimasukkan $1 \mathrm{~mL}$ suspensi bakteri Klebsiella pneumoniae dan disebarkan biakan bakteri dengan menggunakan pipa bentuk L agar suspensi tersebar merata pada media dan diamkan selama 10 menit agar suspensi terserap pada media. Diletakkan kertas cakram Ciprofloxacin (kontrol positif), kertas cakram yang di tetesi larutan CMC (kontrol negatif) dan kertas cakram yang ditetesi larutan uji dengan konsentrasi 80\%, 60\%, 40\%, $20 \%$ dan $10 \%$ menggunakan pinset steril. Dilakukan pengulangan sebanyak 3 kali. Selanjutnya semua media di inkubasi ke dalam inkubator selaama 24 jam pada suhu $37^{\circ} \mathrm{C}$. Lalu diukur zona bening yang terbentuk dengan menggunakan penggaris ukuran millimeter.

\section{b. Metode Sumuran}

Pada pengujian dengan menggunakan metode sumuran, dibuat dengan 2 lapisan media nutrient agar, yaitu dengan cara :

1. Lapisan dasar dibuat dengan menuangkan masing-masing $10 \mathrm{~mL}$ media nutrient agar ke dalam cawan petri kemudian dibiarkan hingga memadat.

2. Lapisan dasar media ditanam 7 pencadang baja dan diatur jaraknya agar daerah pengamatan tidak bertumpu.

3. Suspensi bakteri dicampurkan dalam media nutrient agar

4. Dituangkan $10 \mathrm{~mL}$ media nutrient agar pada tiap cawan petri yang diletakkan pencadang sebagai lapisan kedua. Setelah memadat, pancadang diangkat secara aseptik dari masing-masing cawan petri menggunakan pinset steril. Sehingga terbentuk sumur-sumur.

5. Masing-masing lubang sumuran di isi dengan larutan uji, larutan kontrol positif dan larutan kontrol negatif masing-masing $50 \mu \mathrm{L}$ dilakukan pengulangan sebanyak 3 kali.

6. Selanjutnya semua media diinkubasi pada suhu $37^{0} \mathrm{C}$ selama 24 jam didalam incubator.

\section{Pengukuran Zona Hambat}

Pengamatan dilakukan setelah 1x24 jam masa inkubasi. Zona bening merupakan petunjuk kepekaan mikroba terhadap bahan antimikroba yang digunakan sebagai bahan uji 
yang dinyatakan dengan lebar diameter zona hambat. Diameter zona hambat diukur kemudian dikategorikan kekuatan daya antibakterinya berdasarkan penggolongan Davis dan Stout (1971).

\section{HASIL DAN PEMBAHASAN}

\section{Identifikasi Sampel}

Tanaman Lengkuas Putih (Alpinia galanga L. Willd) yang digunakan dalam penelitian ini di identifikasi pada bagian taksonomi tumbuhan, Jurusan Biologi Fakultas Matematika dan Ilmu Pengetahuan Alam Universitas Sam Ratulangi Manado. Tujuan di lakukannya identifikasi adalah untuk mengetahui kebenaran dari sampel yang di gunakan

\section{Hasil Ekstraksi}

Sampel basah rimpang Lengkuas putih sebanyak $2 \mathrm{~kg}$ yang dibuat menjadi simplisia dan ekstraksi selama 7 hari dengan menggunakan pelarut etanol $96 \%$ menghasilkan filtrat sebanyak $1140 \mathrm{~mL}$. Filtrat yang dihasilkan kemudian di uapkan menggunakan inkubator dengan tujuan menguapkan etanol dari proses maserasi sehingga menghasilkan ekstrak kental rimpang Lengkuas putih sebanyak 9,6 gram. Dari perolehan ekstrak ini, telah dilakukan perhitungan rendemen. Dengan rendemen sampel yang diperoleh yaitu sebesar 7,5\%, rendemen ekstrak yang diperoleh yaitu sebesar $0,83 \%$ dan rendemen total yang diperoleh yaitu sebesar 6,4\%.

\section{a. Metode Sumuran}

Tabel 2. Hasil Pengukuran Diameter Zona Hambat menggunakan Metode Sumuran

\begin{tabular}{|c|c|c|c|c|}
\hline \multicolumn{5}{|c|}{ Diameter Zona Hambat (mm) } \\
\hline Perlakuan & U1 & U2 & U3 & Rata-rata \\
\hline $\mathbf{K}(-)$ & 0 & 0 & 0 & 0 \\
\hline $\mathbf{K}(+)$ & 9,5 & 9 & 9,5 & 9,3 \\
\hline $\mathbf{8 0 \%}$ & 10 & 9,5 & 10 & 9,8 \\
\hline $\mathbf{6 0 \%}$ & 8,5 & 9 & 9,5 & 9 \\
\hline $\mathbf{4 0 \%}$ & 7 & $\mathbf{8 , 5}$ & 8 & 7,8 \\
\hline $\mathbf{2 0 \%}$ & 7,5 & 7,5 & $\mathbf{8 , 7 5}$ & 7,9 \\
\hline $\mathbf{1 0 \%}$ & 7 & 7,75 & 8,5 & 7,7 \\
\hline
\end{tabular}

Uji Aktivitas

\section{b. Metode Cakram}

Tabel 1. Hasil Pengukuran Diameter Zona Hambat menggunakan Metode Cakram

\begin{tabular}{|c|c|c|c|c|}
\hline \multicolumn{5}{|c|}{ Diameter Zona Hambat (mm) } \\
\hline Perlakwan & U1 & U2 & U3 & Rata-rata \\
\hline $\mathbf{K}(-)$ & 0 & 0 & 0 & 0 \\
\hline $\mathbf{K}(+)$ & 11,5 & 10 & 10 & 10,5 \\
\hline $\mathbf{8 0 \%}$ & 11 & 12 & 11 & 11,3 \\
\hline $\mathbf{6 0 \%}$ & 11 & 10 & 10 & 10,3 \\
\hline $\mathbf{4 0 \%}$ & 9 & 9 & 10 & 9,3 \\
\hline $\mathbf{2 0} \%$ & 7 & 5 & 7 & 6,3 \\
\hline $\mathbf{1 0 \%}$ & 4 & 2 & 2 & 2,6 \\
\hline
\end{tabular}

\section{KESIMPULAN}

1. Ekstrak rimpang Lengkuas putih (Alpinia galanga L. Willd) memiliki aktivitas antibakteri terhadap bakteri Klebsiella pneumonia

2. Untuk metode sumuran konsentrasi $80 \%$ dan $60 \%$ termasuk kategori kuat, konsentrasi $40 \%$ dan $20 \%$ termasuk kategori sedang dan konsentrasi $10 \%$ termasuk dalam kategori lemah. Dalam penelitian ini metode sumuran menghasilkan daya hambat yang lebih baik di banding dengan metode cakram. 


\section{SARAN}

Perlu di lakukan penelitian yang lebih lanjut mengenai potensi aktivitas antibakteri dari rimpang Lengkuas putih pada jenis bakteri yang lain.

\section{DAFTAR PUSTAKA}

Aliero, A., Aliero, B. L. and Buhari, U. 2008.

Preliminary phytochemical and antibacterial screening of Scadoxus multiflorus, Int. Jor. P. App. Scs., 2(4):13-17.

Davis, W. W., T.R. Stout. 1971. Disc plate method of microbiological assay. Journal of microbiology 22: 659-665.

Kusriani, R.H.,dan Shofia Az Zahra, 2015, Skrinning Fitokimia dan Penetapan Kadar Senyawa Fenolik Total Ekstrak Rimpang Lengkuas Merah dan Rimpang Lengkuas Putih (Alpinia galangal L.), Prosiding Seminar Nasional Penelitian dan PKM Kesehatan, Vol. 1, No. 1, Hal. 295-302.

Puput, H. S. H. 2019. Uji Daya Hambat Ekstrak Rimpang Lengkuas Putih (Alpinia galanga (L). Willd) Terhadap Pertumbuhan Bakteri Klebsiella pneumoniae Isolat Sputum Pada Penderita Pnemonia Resisten antibiotik Seftriakson. [Skripsi]. Fakultas Matematika dan Ilmu Pengetahuan Alam: Universitas Sam Ratulangi Manado.
Rambiko, C. S., Fatimawali., Bodhi, W. 2016. Uji sensitivitas bakteri penyebab infeksi nosokomial saluran kemih akibat penggunaan kateter terhadap antibiotic ampicillin, amoxicillin dan Ciprofloxacin di RSUP Prof.dr.R.D.Kandou Manado. Jurnal Ilmiah Farmasi Pharmacon.5(1):1-7.

Sinaga, Ernawati. 2005. Alpinia galanga (L) Willd [online]. Pusat Penelitian dan Pengembangan Tumbuhan Obat Universitas Nasional/P3TO UNAS. Jakarta Selatan. Tersedia (http://iptekapiji.or.id/artikel/tent angtanaman obat /unas/ lengkuas. pdf) diakses pada tanggal 2 Januari 2013.

Sutrisna, E. M. 2012. Penggunaan Antibiotik Secara Rasional. Seminar IDI Girobogan, Purwodadi.

Tessy A, Ardayo., Suwanto. 2001. Infeksi salauran kemih dalam Buku Ajar Ilmu Penyakit.Dalam. Jilid 3. Edisi 3. Balai Penerbit FKUI, Jakarta

Yuharmen, Eryanti, dan Nurbalatif. 2002. Uji Aktivitas Antimikroba Minyak Atsiri dan Ekstrak Methanol Lengkuas (Lenguas galang). Jurusan Kimia, FMIPA. Universitas Riau, Riau. 